371.3::811.163.41

811.163.41’367.625

811.163.41'38

https://doi.org/10.18485/kij.2020.67.1.13

НЕНАД С. КРЦИЪ*

Универзитет у Београду

Филолошки факултет
Оригинални научни рад

Примљен:

Прихваћен:

\title{
СТИЛСКЕ ВРЕДНОСТИ ГЛАГОЛСКИХ ОБЛИКА У НАСТАВИ СРПСКОГ ЈЕЗИКА $* *$
}

\begin{abstract}
Након што су се у нижим разредима упознали с глаголским облицима с морфолошке стране, ученици у 8. разреду основне школе усвајају значења и употребе глаголских облика, а то се шире обрађује и у 4. разреду средње школе. Циљ овог рада јесте да испита удео стилистичких информација о овим облицима у актуелним граматикама српског језика за основну и средњу школу и упореди те податке са наставном праксом, на основу анкетног истраживања спроведеног међу наставницима. На основу тих резултата дају се закључци о томе колико су стилске вредности глаголских облика заступљене у настави и како би се настава у овој области могла учинити функционалнијом у контексту планираних измена наставног програма.
\end{abstract}

Кључне речи: глаголски облици, стилска вредност, стилистика, методика, српски језик.

\section{1. Уводне напомене}

Према Наставном програму за осми разред образовања и васпитања ${ }^{1}$ ученици у овом разреду усвајају основне функције и значења глаголских облика, као и употребу глаголских облика у приповедању. ${ }^{2}$ У истом програму наводи се и следеће (истицања курзивом наша):

Савремена методика наставе граматике залаже се да тежиште обраде одређених језичких појава буде засновано на суштинским особеностима, а то значи на њиховим битним

"nenadkrcic@gmail.com

** Овај рад представља измењену и допуњену верзију излагања са 61. републичког зимског семинара за наставнике српског језика (фебруар 2020, Филолошки факултет у Београду).

${ }^{1}$ Исп. www.mp.gov.rs/propisi.

${ }^{2}$ У току писања овог рада од проф. В. Ломпар сазнали смо да планирани нови програм за осми разред предвиђа изостављање обраде значења и употребе глаголских облика. У контексту ових сазнања наша су се схватања о функционалној настави српског језика - која би инсистирала на развијању комуникативних (и стилских) компетенција ученика наместо сувишног „граматизирања” - још више учврстила. 
својствима и стилским функцијама, што подразумева занемаривање формалних и споредних обележја проучаваних језичких појава.

У настави језика нужно је посматрати језичке појаве у животним и језичким околностима које су условиле њихово значење. Ученике ваљь упутити на погодне текстове и говорне ситуаџије у којима се одређена језичка појава природно јавља и испољава.[...]

Наставник ваља да има на уму и то да упознавање суштине језичке појаве често води преко доживљавања и схватања уметничког текста, што ће бити довољно јак подстицај за наставника да што чешће упућује ученике да откривају стилску функиију (изражајност) језичких појава. [...] Кад ученицима постане приступачна стилска (изражајна, експресивна) функција језичке појаве, прихватају је као стваралачки поступак, ито је врло погодан и подстицајан пут да знања о језику брже прелазе у умења, да се на тај начин доприноси бољем писменом и усменом изражавању, али и успешнијој анализи књижевних текстова.

Да бисмо испитали како се томе приступа у настави српског језика, анализирали смо обраду стилских функција глаголских облика у граматикама и спровели анкетно истраживање међу наставницима. Прегледали смо актуелне граматике за основну школу, и то оне које се највише користе у настави - према анкети спроведеној међу наставницима. ${ }^{3}$ У анализи полазимо од једне опште граматике за све разреде (за основну школу - граматика Креативног центра, за средњу - Завода за уџбенике), а затим разматрамо појединачне граматике: три за осми разред (Завод, Клет, Нови Логос) и две за четврти разред средње школе (Клет и Едука).

\section{2. Анализа граматика за основну школу}

1. У Граматищчи српског језика за основну школу Креативног центра (Кликовац 2010: 185-195) налазимо неколике стилистичке податке о употреби глаголских облика. О приповедачком презенту експлицитно се каже да је сликовит (исто: 186): „као да се радње одигравају пред слушаочевим/читаочевим очима: Излазим ја јуче из куће и сретнем Јована: жури некуд. Питам га куда ће, а он се све снебива, неће да каже."

Информација о стилској вредности даје се и за приповедање у перфекту (исто: 187): „Кад су догађаји испричани перфектом, приповедање има мирнији тон него да су испричани приповедачким презентом или аористом”.

За аорист се у истом поглављу наводи (исто: 188): „У говору није чест и обично је стилски обојен - изражава неки емоционалан однос говорника према ономе о чему говори: Ух, испаде ми шерпа из руке. - Чу ли ти њега ономад како лаже?!”, док се за наративни аорист истиче да „у приповедање уноси живост и динамичност”. Имперфекат је ,данас редак - како у народним говорима, тако и у књижевности. Заменио га је перфекат” (исто: 189).

${ }^{3}$ На питање коју граматику користе у настави, наставници основних школа су одговорили (наводимо их према издавачима): Нови Логос (21), Клет (19), Креативни центар (3), Завод за уџбенике (2), Едука (1), ниједну (1), а наставници средњих школа одговорили су: Завод (7), Клет (4), Едука (3), Граматика српскохрватског језика М. Стевановића (2), Синтакса просте реченище, група аутора (1). 
Д. Кликовац бележи да приповедачки императив стоји увек у 2. л. јд.: Аутобус само што није пошао, а ја трчи, трчи - једва стигох (исто: 190), а можда би требало додати као битан податак да је употреба императива у временском значењу изразито стилски маркирана, он се ту употребљава „за стилски јаче обојено приповедање” (Симић, Јовановић 2007: 224), тј. веома је експресиван, а јавља се и у разговорном језику (Кликовац, [Скрипта]: 49).

Коначно, корисна је и прагматичка напомена о ублажавању захтева или тврдње потенцијалом (исто: 191), где се наводе и примери: Хтела бих да прођем (уместо: Хоћу да прођем). - То не би било тачно (уместо: То није тачно). ${ }^{4}$

Дакле, у овој се граматици на више места проговара о стилским функцијама облика и о њиховој комуникативној вредности. Свакако, могло би се указати и на стилску маркираност наративног императива, крњег перфекта, архаичан тон имперфекта (у савременом језику), па и комуникативну вредност плусквамперфекта у систему претериталних времена. ${ }^{5}$

2.2. И у уџбенику за 8. разред Завода за уџбенике Српски језик и језичка култура (Кликовац 2011: 139-148, 151-160) 6 често се говори о стилским одликама глаголских облика - пре свега у приповедању. То се чини обично кроз поређења с другим облицима, кроз питања ${ }^{7}$, али и експлицитно, у дефиницијама: приповедачки презент је ближи, живљи, сликовитији; перфекат уноси миран, сталожен тон; аорист уноси живост и динамичност, није чест у говору и сличан је приповедачком презенту, изражајнији је и упечатљивији од перфекта, изражава емотиван став; имперфекат је редак и заменио га је перфекат ${ }^{8}$ ф футур І уноси живост у приповедање о прошлим догађајима (што се у другим граматикама не помиње) ${ }^{9}$;

${ }^{4}$ Такву напомену срећемо још само у Мразовић, Вукадиновић 2009: 159.

${ }^{5}$ У овом поглављу нема информације о ограниченој употреби овог облика и о томе да га перфекат потискује, но у поглављу о врстама речи (глаголима) за плусквамперфекат који се гради од имперфекта каже се да се он користи „данас ређе, и углавном у књижевности” (Кликовац 2010: 112).

${ }^{6}$ У овом се уџбенику (као и у граматици Креативног центра) не користе термини апсолутно (или индикативно) и релативно значење и нема сувишних теоријских објашњења (исп. објашњење у приручнику - Кликовац и др. 2011б: 81). Сматрамо да ово умногоме олакшава усвајање већ довољно апстрактног градива за ученике овог узраста.

${ }^{7}$ Од ученика се тражи да презент замене перфектом у одломку Приче о Раку Кројачу Десанке Максимовић (Кликовац 2011: 140): „Какву разлику међу њима осећаш? Која је радња 'ближа' читаоцу, а самим тим живља и сликовитија?” У поглављу о перфекту (исто: 142, 143) срећемо сличне захтеве. Један је и нарочито функционалан јер је за предложак узет одломак Андрићеве приповетке Аска и вук који је посебно напет, узбудљив, сликовит. И код аориста се кроз примере и питања ученици мотивишу да уоче стилске вредности тог облика, а указује се и на обим употребе (исто).

${ }^{8}$ Исп. Кликовац (2011: 146): „Имперфекат се практично више не употребљава. Који глаголски облик бисмо данас употребили уместо имперфекта? [...] Данас је имперфекат изузетно редак и заменио га је перфекат.” Такође, у 12. задатку на истој страни поставља се питање којим глаголским обликом у датом одломку из Сеоба Црњанског може да се замени имперфекат, те каква се разлика осећа између та два облика.

${ }^{9}$ У лекцији о футуру I среће се захтев да се тај облик замени другим обликом у одломку а да значење остане исто и питање (Кликовац 2011: 147): „Да ли би замена перфектом утицала на живост приповедања?” Тим питањем се пак ученику открива одговор на претходно постављени захтев, но ово је и једина граматика у којој се помиње стилска разлика у приповедању перфектом и футуром I који означава прошлу радњу. 
приповедачки императив је живљи, динамичнији од презента ${ }^{10}$; захтев или тврдња исказана потенцијалом је блажа. Можда би се код плусквамперфекта (који се гради од имперфекта помоћног глагола) и имперфекта могле додати напомене о архаичности. ${ }^{11}$

И замена инфинитива конструкцијом $\partial a+$ презент може се сматрати стилски релевантном ${ }^{12}$, ако је посматрамо као врсту дијатопијске варијације, али и ако се посматра колико се често инфинитив јавља у одређеним врстама текста, спрам $\partial a$-конструкције, која је у неким условима чешћа у разговорном језику. ${ }^{13}$ У уџбенику се наводи да су у књижевном језику обе подједнако правилне, те да је у (и)јекавском изговору инфинитив чешћи (исто: 156). ${ }^{14}$

2.3. У уџбенику Српски језик за 8. разред основне школе Клета помиње се синонимија глаголских облика и наводе примери (Ломпар 2020: 58): „И тако царев син чекаше у заседи три дана. И тако царев син чека у заседи три дана. И тако ће царев син чекати у заседи три дана.” Иако јесу синонимни, чини се да би овде било корисно указати и на то да се разлика у употреби ових облика огледа управо у стилским вредностима, односно у разноврсним стилским ефектима који се овим облицима постижу, будући да је први наведени данас архаичан, док су друга два релативно употребљена, те приказују чекање царевог сина на различите начине, из различитих перспектива. Стога би на том месту било тачније рећи да се „у приповедању могу употребити различити глаголски облици” - са одређеним стилским разликама. ${ }^{15}$ Ово, такође, указује и на важну чињеницу

${ }^{10}$ Исп. и у лекцији о императиву: „Која реченица делује живље, динамичније: $а$ он онда побјегне или а он онда бјежи?" (Кликовац 2011: 151).

${ }^{11}$ У тексту се напомиње да се он више не употребљава и да је редак, али се не каже експлицитно и да уноси - архаичан тон. Ипак, у предвиђеном одговору на захтев који је постављен у тој лекцији каже се да би се имперфекат могао заменити перфектом, и тада „значење остаје исто, али текст више није архаичан” (Кликовац и др. 2011: 84). Сматрамо да би тај податак у граматици могао бити исказан експлицитно.

${ }^{12}$ У оквиру факултативне дистибуције „некада је чешћи инфинитив, а некада да-конструкција, с могућим разликама у њиховој стилској вредности” (Пипер и др. 2005: 325). Нагомилавање конструкција са истим облицима „може зависити и од функционалног стила којем таква реченица припада. На пример, не могу се сматрати ненормативним у лепој књижевности или у разговорном стилу реченице као што је [...] Речено им је да треба да дођу [...] Општа нормативна препорука ипак би била да се из стилских разлога таква нагомилавања избегавају" (исто: 327; о овоме исп. и Стевановић 1979: 599-600). Такође, економичност израза и тежња да исказ не буде личан одлике су научног и административног стила, „где су стога услови за употребу инфинитива начелно повољнији (нпр. Закон се има поштовати у свакој прилици)" (исто: 328 ).

${ }^{13}$ Нпр. у оквиру футуроида је „више карактеристична за колоквијално изражавање” (Пипер и др. 2005: 327). Стевановић (1979: 602-603) чак истиче да није „оправдано тврдити да футур с таквим другим делом није особина књижевног језика”, али има и другачијих мишљења (исп. Ковачевић 2014). О њему се не говори у настави српског језика, иако је чест у разговорном језику (с друге стране, имперфекат се помиње у граматикама, некад и без упућивања на комуникативну вредност).

${ }^{14}$ У радној свесци која иде уз ову граматику у једном задатку испитује се стилска вредност перфекта према презенту у приповедању (Кликовац 2011a: 62). Предвиђени одговор: „Перфекат чини приповедање мирнијим, објективнијим” (Кликовац и др. 2011б: 89).

${ }^{15}$ Исп. Симић, Јовановић (2007: 220) о замени аориста презентом и перфектом: „Интересантно је да замена аориста са ова два облика - вероватно из стилских разлога - није увек равноправна". 
да ти облици нису равноправни у систему глаголских облика - из перспективе њихове комуникативне вредности.

Стилске вредности личних глаголских облика помињу се само на два места у оквиру овог поглавља - кроз поређења са приповедањем у перфекту, тј. у питањима која следе иза задатака (Ломпар 2020: 60, 62): у лекцији о презенту даје се задатак у коме је неопходно подвући глаголе у приповедачком презенту и напомиње се да се они могу препознати по томе што их је могуће заменити перфектом; у лекцији о аористу, након напомене да се релативни аорист најчешће употребљава у приповедању, од ученика се тражи да у одломку замене аорист перфектом. ${ }^{16}$ До краја поглавља говори се о грађењу и значењу ових облика, али не и о њиховој стилској, употребној или комуникативној вредности. Тако, на пример, код имперфекта нема напомене о томе да је његова употреба данас ограничена. ${ }^{17}$

2.4. У граматици за осми разред основне школе Дар речи Новог Логоса (Ћећез-Иљукић и др. 2016) више се простора посвећује стилским вредностима глаголских облика, пре свега кроз задатке и питања (то се прво чини у оквиру поглавља о презенту и перфекту). ${ }^{18}$

Истиче се, између осталог, употребна вредност крњег перфекта (исто: 119): користи се у приповедању, а у савременом језику чест је у новинским насловима.

О аористу се и овде каже да „у приповедање уноси живост, динамичност” (исто: 123). ${ }^{19}$ У вези с плусквамперфектом у граматици се поставља питање о његовој употребној вредности (исто: 124): „Кад користиш плусквамперфекат? Који његов облик чујеш чешће?" Међутим, сем напомене да се најчешће употребљава у приповедању, ни у овој граматици се не говори о архаичности кад се гради од имперфекта, као ни о томе да га перфекат потискује. С друге стране, за императив се даје такав податак (исто: 128): „Данас се императив не користи у приповедању, али су га писци некада користили (у старијој књижевности и у народним говорима).” Међутим, из овога би се дало закључити да се овакав императив (у временском значењу) не користи, што не би било сасвим тачно - он се среће у разговорном језику (исп. Кликовац, [Скрипта]: 49).

Занимљива су и питања у лекцији о глаголском прилогу прошлом: „Колико често употребљаваш тај облик? [...] Јеси ли негде прочитао/-ла или чуо/-ла за облик ушав?”, која могу послужити као увод у краћи разговор о ограниченој, ређој употреби овог облика, те и његовој маркираности.

${ }^{16}$ И код презента и код аориста поставља се питање: „Да ли је приповедање живописније када се користи презент или кад се користи перфекат?” (Ломпар 2020: 60), „Које ти се приповедање чини упечатљивијим - са аористом или са перфектом?” (исто: 62).

${ }^{17}$ У радној свесци која иде уз ову граматику, у поглављу о значењима и употребама гл. облика (Ломпар 2020: 45-53), нема захтева или питања која се тичу стилске вредности облика.

${ }^{18}$ Тако се код презента тражи од ученика да замене облике презента перфектом, упореде их и запазе разлику, а у следећем задатку да напишу пример за приповедачки презент из свакодневног живота (Ћећез Иљукић и др. 2016: 117). И у лекцији о перфекту тражи се од ученика да упореде ова два облика (исто: 119): „Шта закључујеш? Када је приповедање динамичније, напетије?”

${ }^{19}$ Исп.: „,[...] замени облике аориста перфектом у реченици под в). Када је приповедање спорије?” 
Дакле, можемо закључити да се у овој граматици посвећује пажња стилским вредностима облика; ипак, за приповедачки императив се напомиње да су га користили старији писци, што није потпуна информација, а за неке облике се не наводе одлике. ${ }^{20}$

\begin{tabular}{|l|c|c|c|c|}
\hline & $\begin{array}{c}\text { Креативни } \\
\text { центар }\end{array}$ & Завод & Klett & $\begin{array}{c}\text { Нови } \\
\text { Логос }\end{array}$ \\
\hline презент & + & + & + & + \\
\hline перфекат & + & + & $(+)$ & + \\
\hline крњи перфекат & & + & & + \\
\hline футур I & + & + & + & + \\
\hline аорист & $(+)$ & $(+)$ & & $(+)$ \\
\hline имперфекат & $(+)$ & & & \\
\hline плусквамперфекат & & + & & $(+)^{*}$ \\
\hline футур ІІ & + & + & & \\
\hline потенцијал & & $(+)$ & & \\
\hline императив & & & & \\
\hline инфинитив & & & & \\
\hline глаголски прилози & & & & \\
\hline глаголски придеви & & & & \\
\hline
\end{tabular}

Табела 1. Стилске вредности глаголских облика у граматикама за основну иколу ${ }^{21}$

Шта можемо закључити на основу овог прегледа основношколских граматика?

У већини случајева маркираност облика представљена је кроз интерогативну форму или компарацију два облика у тексту, чиме се поштују методички принципи поступности и самосталног откривања. Стилске оцене којима се описује

${ }^{20}$ У радној свесци која иде уз ову граматику, у делу који се тиче значења и употреба глаголских облика (Шошо и др. 2016: 108-111), нема задатака посвећених стилским вредностима ових облика.

21 Знак у загради (+) значи да је у граматици истакнута обично употребна вредност облика на основу које се може наслутити и стилска вредност или је она на неки имплицитни начин дата, а не експлицитно (нпр. тиме што се говори о ограниченој употреби плусквамперфекта и гл. прил. прошлог сугерише се да би њихова употреба у одређеном контексту могла бити маркирана, стилогена; поређење са перфектом у лекцијама о презенту и аористу имплицира и стилску вредност перфекта). Знак +* користи се код објашњења која не сматрамо у потпуности тачним. 
употреба глаголских облика у приповедању често се исказују у компаративу: ближе, сликовитије, динамичније, живље (уноси живост), живописније, напетије, упечатљљивије, спорије, мирније, сталоженије. ${ }^{22}$

Уочљиве су разлике у начину обраде стилске вредности глаголских облика, као и несразмеран приступ овом делу градива. Наиме, ни у једној граматици се не говори подједнако о стилским вредностима глаголских облика. По броју поменутих стилских одлика издвајају се Логосова и нарочито Заводова граматика, а предност друге је и у томе што не инсистира на, за овај узраст, непотребној терминологији из синтаксе глаголских облика. Ипак, ни у једној граматици нису представљене стилске вредности свих глаголских облика, мада има разлога да тако буде: упућивање ученика на употребну и стилску вредност одређеног облика утиче на њихову језичку компетенцију, богаћење њихових језичких и стилских потенцијала, боље разумевање прочитаног итд. ${ }^{23}$ Разлоге за неједнаку заступљеност овог питања у уџбеницима можемо потражити пре свега у недовољно прецизном програму за основну школу, којим је одређено да се у осмом разреду обрађују основне функције и значења глаголских облика, те се тиме, како наводи и Д. Кликовац у приручнику за наставнике (в. Кликовац и др. 2011б: 81), аутору уџбеника оставља да сам процени шта би било основно за овај узраст. Ипак, треба се запитати шта би било сврсисходније: да ли је заиста неопходно да ученици тог узраста првенствено знају како се граде сви глаголски облици, шта је апсолутно/индикативно, релативно, модално значење (мада је ово последње често врло апстрактно и тешко савладиво и за многе студенте - са чиме смо се у настави сусретали) или да се оспособе да препознају и користе те облике у различитим комуникативним ситуацијама и функционалним стиловима?

\section{3. Анализа граматика за средњу школу}

3.1. Погледаћемо прво како се у Граматици српског језика за средње школе Станојчића и Поповића (2010) приступа стилским вредностима ових облика.

Помиње се употреба крњег перфекта у насловима новинских чланака (са доста примера). Он ту „носи и информацију о новости радње” (Станојчић/Поповић 2010: 393).

И овде се говори о динамичности коју уноси аорист у приповедање, њиме „писац приближава читаоцу радњу - као доживљену, па отуда упечатљивију” (исто: 396). Важна је напомена да се ,аорист имперфективних глагола врло мало употребљава чак и у приповедачком стилу, а поготову га мало има у разговорном језику. Аорист перфективних глагола употребљава се у књижевном језику, посебно у уметничкој књижевности, много више, док га у језику других стилова (научном, стручном и сл.) углавном нема" (исто: 397 ).

\footnotetext{
${ }^{22}$ У приручнику за наставнике налазимо за перфекат и - смиреније, ,хладније” (в. Кликовац и др. 2011a: 84), он чини приповедање мирнијим, објективнијим (исто: 89).

${ }^{23} \mathrm{O}$ развијању стилских компетенција ученика у настави в. Крцић 2018.
} 
Погрешна је констатација да је имперфекат „само релативно време”, али се исправно наводи да се највише користи у језику уметничке књижевности, као наративни облик (исто).

За аорист и имперфекат се каже и да се повлаче пред перфектом, но аорист несвршених глагола је ,још жива категорија у језику уметничке књижевности. [...] Имперфекат, међутим, врло је редак, и налази се углавном код писаца који негују класични језик наше књижевности" (исто: 398).

О плусквамперфекту наводи се да је све ређе у употреби, посебно са имперфектом помоћног глагола, који „даје тексту архаичан тон” (исто: 399).

Не слажемо се са запажањем да се наративни императив у конкуренцији са наративним аористом, презентом и крњим перфектом „скоро потпуно изгубио из савременог језика" (исто), јер, као што смо већ горе рекли - он постоји у разговорном језику.

За чисто временско значење футура II у облику пасива у приповедању, како се овде наводи, граматике дају мало примера, „углавном из старијих језичких фаза нашег књижевног језика, или из текстова писаца који негују класични вуковски израз језика" (исто: 402). ${ }^{24}$

Коначно, за глаголски прилог прошли од несвршених глагола наводи се да „у модерном језику представља - архаизам” (исто: 405).

3.2. У граматици за 4. разред гимназија и средњих школа чији је издавач Клет (Ломпар, Антић 2016) говори се о стилским вредностима глаголских облика, очекивано, далеко више него у уџбенику за 8. разред истог издавача.

Крњи перфекат се од перфекта „разликује по стилској вредности, јер означава емоционални став према неком догађају, па је у употреби најчешће експресиван” (исто: 115). И овде се помиње употреба у насловима, а на маргини стоји и питање (исто: 116): „Можеш ли да се сетиш примера за употребу крњег перфекта у административном стилу?” Мисли се на употребу овог облика у биографијама: Pођен у H. Cmyдирао у Б. итд. ${ }^{25}$

За плусквамперфекат који се гради од имперфекта наводи се да има ,архаичан призвук”: нпр. Мај већ беше прошао (исто), а затим и то да се овај глаголски облик чешће среће у књижевноуметничком стилу, што се показује на примеру (исто: 117).

Емоционални став и екпресивност помињу се и код аориста, док приповедачки аорист уноси динамичност (исто).

У делу где се наводе занимљивости, пореде се глаголски облици за означавање прошлости, уз напомену да се њихова употреба разликује (исто 118): „У свим функционалним стиловима перфекат је најчешћи, јер је стилски неутралан, а у разговорном и књижевно-уметничком стилу су, уз њега, у приповедању чести приповедачки аорист и презент. Они су стилски обележени, јер уносе

\footnotetext{
${ }^{24}$ Исп. примере: „Тада Јаков буде позван у Београд. - Не може човјек ништа примати, ако му не буде дано - И тако буду четири поста изабрана" (Станојчић/Поповић 2010: 402).

${ }^{25}$ Ни овде ни у другим граматикама се не спомиње нарочита употреба крњег перфекта у жаргону.
} 
динамичност у приповедање.” У наставку се даје исти текст са овим, стилски обележеним облицима, а затим са перфектом, поређења ради. Наводи се да се перфекат не замењује другим глаголским облицима у краћим облицима новинарског стила, у научном и административном стилу. ${ }^{26}$

Ауторке помињу и стилску вредност имперфекта, као и то да се у говорном језику он скоро сасвим изгубио - употребљава се још увек у устаљеним питањима с глаголима бити и звати (исто: 118, 119).

Указује се и на јаче императивно значење футура I - на маргини. ${ }^{27}$

Временско значење императива јавља се у приповедању, „када се њиме, из стилских разлога, означе прошле радње”, само у 2. л. јд. (исто: 121).

Можемо поменути и то да се кроз питања на маргини уводи облик потенцијала прошлог, који је занимљив с аспекта комуникативне, употребне вредности. Како се наводи и на крају књиге, употребљава се ретко, а примери се могу наћи у књижевним делима: Турска би била трајала још столеће (исто: 243).

На крају читавог овог поглавља говори се о заменљивости облика и истиче да су најупечатљивији примери замене једног облика другим кад означавају прошлост: сви облици стилски су - мање или више - обележени, сем перфекта који је стилски неутралан (исто: 122). ${ }^{28}$

3.3. У Едукиној граматици за 4. разред средње школе објашњава се, преко примера, „стилска нијанса” приповедачких облика (Кликовац 2018: 76): перфекат уноси „најмирнији тон”, аорист и презент износе радњу динамичније, презент несвршених глагола износи радњу „као да се одвија пред нашим очима”. ${ }^{29}$

У делу о перфекту помиње се његова употреба с модалном речцом да (Да си се одмах извинио! Да се нисте ни макли!), када означава строгу заповест или забрану (исто: 82). Тиме се имплицира и стилска природа перфекта, јер је заповест овде јаче исказана него са императивом, као и у случају већ поменутог футура I.

И код крњег перфекта се помињу „стилске нијансе” (исп. исто: 82-83), а наводи се да се користи и у кратким извештајима (исп. горе у граматици Клета: у биографијама).

Већ истакнуте одлике аориста (није чест, изражајан, емоционалан) и имперфекта (изгубио се у дијалектима, ретко се користи у књижевности) и овде се помињу (исто: 85,87$){ }^{30}$

\footnotetext{
${ }^{26}$ Занимљиви су примери на крају тог текста (Ломпар/Антић 2016: 118): „Ево како би изгледале вести када би се у њима појавио аорист уместо перфекта: Јуче у позоришту сазнасмо да се не стекоше услови за премијеру мјузикла [итд.]."

${ }^{27}$ Исп. питање (Ломпар, Антић 2016: 120): „Шта мислиш, да ли је императивно значење јаче у реченици Прочитаћеш то сада или у реченици Прочитај то сада?"

${ }^{28}$ Вежбања доносе свега неколико задатака (од укупно 67) који се тичу стилске вредности глаголских облика: у 32. о претериталним временима и динамичности у приповедању; 36. даје примере вести с аористом и перфектом (треба заокружити адекватан облик вести); у 38. задатку треба препознати који текст илуструје научни, а који административни стил.

${ }^{29}$ У лекцији о презенту даје се и задатак у ком се истиче поменути стилски ефекат: у њему презенте свршених глагола треба заменити презентом несвршених глагола (Кликовац 2018: 79).

${ }^{30}$ Код имперфекта се испод прозног одломка пита и како облици имперфекта стилски „боје” текст и наводи се да се он ретко користи у савременој књижевности. На следећој страни даје се
} 
У лекцији о футуру од ученика се тражи да упореде приповедачки футур из текста и презент (који би га могао заменити) и поставља се питање: који облик има већу стилску вредност? (исто: 89). Указује се и на поменуту разлику између футура и императива, а напомиње се и да се футуром може ублажити тврдња: Замолићемо нашег саговорника да нам то објасни (исто). То се може учинити и потенцијалом (исто: 93), како је већ поменуто. Помиње се и потенцијал други (на маргини), који се „не употребљава често” (исто: 92).

Стилске одлике императива се и овде разматрају: „Која реченица делује живље, динамичније: а он онда потера за њима или а он онда терај за њима?” (исто: 95).

Инфинитив, како се наводи (исто: 96), алтернира са конструкцијом да+презент; упућује се - на маргини - и на то да инфинитив потискује та конструкција у екавским говорима, што, како смо већ рекли, имплицира и стилске особености те алтернације. ${ }^{31}$

\begin{tabular}{|l|c|c|c|}
\hline & Завод & Klett & Едука \\
\hline презент & & + & + \\
\hline перфекат & & + & + \\
\hline крњи перфекат & + & + & + \\
\hline футур I & & + & + \\
\hline аорист & + & + & + \\
\hline имперфекат & + & + & + \\
\hline плусквамперфекат & + & $(+)$ & $(+)$ \\
\hline футур ІІ & & $(+)$ & + \\
\hline потенцијал & & & $(+)$ \\
\hline потенцијал прошли & $(+)^{*}$ & & \\
\hline императив & & & + \\
\hline инфинитив & + & & + \\
\hline глаголски прилози & & & + \\
\hline глаголски придеви & & & + \\
\hline
\end{tabular}

Табела 2. Стилске вредности глаголских облика у граматикама за средюу школу

одломак из превода Силмарилиона, испод чега стоји питање: „Којим све језичким средствима је архаизован текст?” (исто: 88).

${ }^{31}$ Овде се говори и о облицима попут Сутра ћу да идем, што се у другим граматикама не чини. На 97. страни наводи се и нормативна напомена о конструкцијама попут Имате ли шта за појести? (она је и имплицитно стилистичка, јер се ради о облику који је чест у разговорном језику). 
3.4. Граматика Станојчића и Поповића (2010) - иако има мањкавости у обради самих значења глаголских облика - у стилистичком смислу даје неке информације о вредности тих облика, али не код свих (исп. Табелу 2). Упадљива је разлика у обради стилских вредности глаголских облика у граматикама издавачке куће Клет за основну и средњу школу: док се у оној за основну то помиње узгред, у свега два наврата, овде се даје доста стилски релевантних података о већини глаголских облика, што сугерише и одређен приступ аутора: у основној школи дају се само основне информације. ${ }^{32}$ У Едукиној граматици за средњу школу уочавамо готово и највише стилистичких информација о глаголским облицима. Извесне разлике огледају се у томе што се у Клетовој граматици даје пар напомена о употреби ових облика у различитим функционалним стиловима и помиње архаичност плусквамперфекта који се гради од имперфекта глагола бити; у Едукиној се пак наводе стилска вредност потенцијала, те више стилских вредности футура I: помиње се приповедачки футур, имплицитно се указује на стилску разлику између заповести исказане императивом и футуром, те се говори и о ублажавању тврдње овим обликом.

\section{3. Истраживање}

Како бисмо испитали стање у наставној пракси, тј. колико се и како обрађују стилске вредности глаголских облика у настави, спровели смо анкетно истраживање међу наставницима српског језика у основним и средњим школама. Анонимни упитник наставници су попуњавали у децембру 2019. године. У наставку рада представићемо резултате упитника.

У истраживању је учествовало укупно 60 испитаника: 47 наставника из основне школе и 13 наставника из гимназија и средњих стручних школа.

Око 25\% анкетираних наставника сматра да учење значења глаголских облика за ученике није нарочито важно, исти број наставника сматра да је - врло важно, 30\% наставника да је - важно, неколицина да је - просечно важно, а неколицина да значења треба обрадити само на основном нивоу. Међутим, из неких одговора наставника који су сматрали да је важно уочава се да су мислили на учење самих облика (с морфолошке стране), а не на значење, исп. одговоре: „да би ученици првенствено препознавали [облике] при читању”, „због конструкције реченица", ,jер све више употребљавају конструкције налик оним у енглеском језику”, „због правилног изражавања”, „да науче како се не каже плакајућu” и сл. С друге стране, неки наставници који су сматрали да ученици то не треба да уче, образложили су свој одговор тиме да је многим ученицима то апстрактно и тешко, да мали број ученика савлада ту област, да то треба обрађивати на додатној настави, у припреми за такмичења, у језичким гимназијама и сл. ${ }^{33}$

\footnotetext{
${ }^{32}$ Ипак, с тим у вези би се могло поставити питање: нису ли управо вредносне одлике оно што би ученицима било лакше и сврсисходније да усвоје на основношколском нивоу (који облик уноси живост, који смирен тон, који ублажава израз, који га чини старинским и сл.), без упућивања на значења?

${ }^{33}$ Овакве смо одговоре добијали од наставника и на радионици на Републичком зимском семинару.
} 
Одговори на питање у вези са употребом аориста показују следеће: око 65\% наставника сматра да би ученике пре свега требало научити да је аорист експресиван (тј. да уноси емоционалност, живост, динамичност), док око 22\% наставника мисли да би их прво требало упознати са тиме која значења он има. ${ }^{34}$

Чак око 77\% испитаних одговорило је да би ученике пре свега требало научити да имперфекат нестаје из употребе и да је архаичан у савременом језику, а око $12 \%$ рекло је да би прво требало научити значење. ${ }^{35}$

На питање о крњем перфекту, око 63\% наставника одговорило је да мисли да би ученике прво требало упознати са тиме у којим се стиловима и текстовима користи, а око $28 \%$ да би их прво требало научити да је експресиван. ${ }^{36}$

Како резултати нашег испитивања показују, 35\% наставника само успутно помене стилске вредности глаголских облика на часу, 30\% обрађује то питање мањи део времена предвиђеног за обраду значења и употреба глаголских облика, око 18\% - половину укупног времена, а 10\% већи део тог времена. Само је један наставник одговорио да то не обрађује с ученицима на часу.

Графикон 1. Обрада стилске маркираности глаголских облика у настави

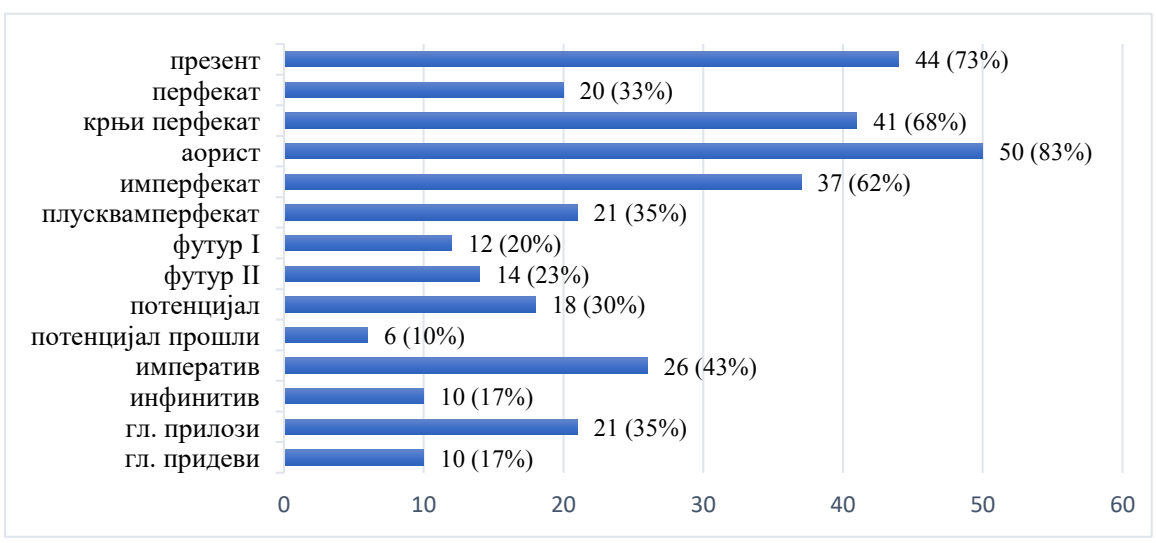

\footnotetext{
${ }^{34}$ Остали одговори: „и једно и друго” (2 одговора), „писање” (2 одговора), „ништа”, „да се гради од свршених глагола", „да се у свакодневном говору мање користи те да се његова употреба свела на књижевне текстове у које уноси експресивност”, „да је преузео функцију изумирућег имперфекта”.

${ }^{35}$ Остали одговори: „да означава доживљену прошлу радњу која је трајала”, „како се правилно пише”, „да је архаичан, али и да постоји у народној књижевности и народним говорима”, „да је архаичан али и да га науче, како не би изумро”, „и једно и друго, да се користи у народној поезији”, „да је присутан облик у енглеском језику”, „да је неопходан као експресивно изражајно средство”. Последњи одговор је веома интересантан из стилистичке перспективе јер имперфекат посматра као нужно средство - за архаизацију.

${ }^{36}$ Остали одговори: „оба претходна одговора”, „његова употреба у свакодневном говору, жељама, клетвама, па после у новинским насловима, оба иду подједнако” „само да знају да постоји и опција перфекта без помоћног глагола”, „да га препознају и разумеју изостављање помоћног глагола”, „разлику између њега и перфекта”.
} 
Према анкети, у настави се најчешће помиње стилска маркираност аориста $(83 \%)$, презента (73\%), крњег перфекта (68\%) и имперфекта $(62 \%)$ - исп. Графикон 1.

Када су упитани које стилске вредности глаголских облика истичу на часовима, наставници су одговарали (наводимо неке од најчешћих одговора): „експресивност” (у 16 одговора), „динамичност” (у 13 одговора), ,архаичност” (6 одговора), „живост” (5 одговора), а у неколико одговора помињу се и „звучност” и „наративност”, а по једном, између осталог, јављају се „изражајност” „живописност”, „упечатљивост”, „уверљивост”, „актуелност”. Двоје наставника је одговорило да за то нема времена у настави.

Према анкети, око 58\% наставника у току анализе књижевног дела повремено говори о стилским вредностима глаголских облика, 27\% редовно, 10\% ретко, док 5\% не говори о томе. Притом, 20\% испитаних рекло је да не користи посебне текстуалне примере за обраду стилских вредности глаголских облика (нпр. када говоре о приповедању презентом или аористом ум. перфектом, употреби крњег перфекта и сл.), 50\% користи (махом књижевноуметничке текстове, ређе новинске, врло ретко - примере из разговорног језика; један одговор је садржао и научно-популарне текстове, а ниједан није поменуо научне или др.).

Такође, 47\% испитаних ослања се на граматику (уџбеник) у великој мери, $20 \%$ повремено, 20\% - мало, а око 8\% уопште не користи уџбеник када обрађује ову област. На питање да ли уџбеник који користе добро обрађује проблем стилске обележености гл. облика, око $27 \%$ наставника је одговорило потврдно $37,47 \%$ је рекло - делимично, 20\% сматра да уџбеник то не обрађује добро, а 5\% наводи да се у уџбенику то не помиње..$^{38}$

Једна четвртина испитаних мисли да у уџбеницима недостаје више примера (који би били „разноврсни”, „ученику блиски”, „конкретни”, „из свакодневног говора") у лекцијама које се односе на значења и употребе глаголских облика. Око 20\% пак мисли да у уџбеницима не недостаје ништа. ${ }^{39}$ Како сматрају испитани наставници, највише стилских информација се у уџбеницима даје о презенту (25\% одговора), имперфекту (25\%), те аористу (20\%), што се, како смо видели, у основи може сматрати тачним - сем у чињеници да се у неким основношколским граматикама, зачуђујуће, не истиче маркираност имперфекта, а у Станојчић, Поповић 2010 не говори се о стилским одликама презента. Око 35\% њих сматра да је важније да ученици основне школе савладају да ли глаголски

${ }^{37}$ Исп. одговор наставника средње школе: „Заводов не, Едукин да”. Одговор на наредно питање открива разлог за овакав став: „У Заводовој граматици за средње школе генерално недостаје угледни текст."

${ }^{38}$ Овај одговор дали су наставници основне школе који користе уџбеник Едуке и Новог Логоса. Ипак, у граматици Новог Логоса се, како смо видели, говори о стилским вредностима гл. облика.

${ }^{39}$ Остали одговори су разноврсни: „слаби су и монотони”, „осмацима је то сувишно”, „недостаје доседна подела значења гл. облика”, „прегледност, терминолошка јасност и доследност”, „наставнику је препуштено да ученицима скрене пажњу на употребу глаголског облика у свакодневном животу или у књижевноуметничким делима”, „уџбеници нису усаглашени око значења гл. облика”, „лекција није прилагођена узрасту, преобимна је”, итд. 
облик може унети миран или динамичан тон у изражавање, да ли се користи у одређеним врстама текста, стиловима и сл., $25 \%$ сматра да је важније да усвоје која значења глаголски облик има, а $37 \%$ мисли да је подједнако важно да савладају и једно и друго. ${ }^{40}$

Чак 55\% анкетираних наставника не поставља питања која се тичу стилских особина глаголских облика на усменим и писменим проверама знања, око $45 \%$ испитује ову област (од тога је скоро половина рекла да то чини повремено, ретко). Двоје наставника је рекло да то чини на часовима додатне наставе, као део припреме за такмичење. Наставнике смо питали и колико добро ученици усвоје тај део градива, а одговори сугеришу да тешко савлађују значења глаголских облика. ${ }^{41}$

\section{3. Закључне напомене}

Стилске вредности глаголских облика нису у свакој граматици за основну школу подједнако и на исти начин обрађене. Општа граматика даје доста података и примера, а од појединачних (за 8. разред) више података и илустративних примера дају граматике Логоса и Завода, а мање се информација о стилским вредностима може наћи у граматици Клета.

У граматикама за средњу школу овом питању, очекивано, посвећено је много више пажње. Граматика Завода даје одређене податке за неке облике, али не указује на стилске одлике, на пример, презента, перфекта, футура I. Од појединачних - врло су информативне граматике Клета и Едуке и имају илустративне примере. Ипак, ниједна не говори о комуникативним и стилским вредностима свих облика - што сматрамо важним.

Сматрамо - а на то нас упућују и резултати истраживања - да је за развијање језичких компетенција важно да ученици стекну знање о томе какве вредности и функције имају глаголски облици, те и да је сувише апстрактно упућивати их на индикативно, релативно и др. значења на том узрасту. Отуда, било би природно да се фокус са граматичких питања у овом случају пребаци на (функционално-)стилска и комуникативна, како би настава језика била функционалнија. Слажемо се са мишљењем испитаних наставника који сматрају да градива има много у основној школи: наиме, ученик осмог разреда већ познаје бројне граматичке термине, а очекује се да усвоји и термине индикативно, релативно, модално, квалификативно значење. Такође, делује помало апсурдно ситуација - а она се из анализе граматика и анкете намеће као чињенична - у којој би ученик основне школе морао да зна да ли перфекат у неком тексту има школи",

${ }^{40}$ Остали одговори: „да правилно користе и пишу гл. облике”, „превише је градива у основној

${ }^{41}$ Исп. одговоре: „теже, то већ залази у област апстрактнијег мишљења”, „врло мало”, „слабо” и сл. О усвајању стилске функције гл. облика исп. одговор: „Боље него значења, пошто се тиме бавимо и на часовима књижевности". 
релативно значење, али не и да зна да ће, на пример, у његово описивање какве ситуације перфекат унети миран, сталожен тон, да нису сви облици једнаки и равноправни (неки су свакодневни, неутрални, неки ретки, архаични), да не зна у којим се текстовима и стиловима користе одређени облици, да не зна да се исказ може одређеним обликом нијансирати - ублажити, појачати, динамизовати и сл. Комуникативне и стилске вредности, отуда, према нашем мишљењу, треба ставити у први план, употребу термина свести на минимум, а обраду значења глаголских облика изоставити на том узрасту.

\section{ИЗВОРИ}

Граматике, приручници и радне свеске за основну школу

Кликовац 2010: Д. Кликовац, Граматика српског језика за основну школу, Београд: Креативни центар.

Кликовац 2011: Д. Кликовац, Српски језик и језичка култура за 8. разред основне школе, Београд: Завод за уџбенике.

Кликовац и др. 2011а: Д. Кликовац, Љ. Бајић, 3. Мркаљ, Радна свеска за српски језик и књижевност за 8. разред основне школе, Београд: Завод за уџбенике.

Кликовац и др. 2011а: Д. Кликовац, Љ. Бајић, 3. Мркаљ, Настава српског језика и књижевности за 8. разред основне школе: приручник за наставнике, Београд: Завод за уџбенике.

Ломпар 2020: В. Ломпар, Граматика 8: српски језик за осми разред основне школе, Београд: Klett.

Ломпар и др. 2020: В. Ломпар, 3. Несторовић, 3. Грушановић, Српски језик за 8. разред основне школе: радна свеска уз уибенички комплет, Београд: Klett.

Ћећез Иљукић и др. 2016: Д. Ћећез-Иљукић, Ј. Срдић, С. Савковић, С. Вулић, Дар речи: граматика за осми разред основне иколе, Београд: Нови Логос.

Шошо и др. 2016: Наташа Станковић-Шошо, Драгана Ћећез-Иљукић, Јелена Срдић, Слађана Савковић, Светлана Вулић, Радна свеска за уибенички комплет српског језика за осми разред основне школе, Београд: Нови Логос.

\section{Граматике за средњу школу}

Кликовац 2018: Душка Кликовац, Српски језик за четврти разред гимназија и средњих стручних школа, Београд: Едука.

Ломпар/Антић 2016: Весна Ломпар, Александра Антић, Граматика: Cpnски језик и књижевност за четврти разред гимназија и средњих стручних школа, Београд: Klett.

Станојчић/Поповић 2010: Ж. Станојчић, Љ. Поповић, Граматика српског језика за гимназије и средње школе, Београд: Завод за уџбенике. 


\section{ЛИТЕРАТУРА}

Кликовац, [Скрипта]: Д. Кликовац, Скрипта из предмета Синтакса српског језика, <https://sintaksa.fil.rs/wp-content/uploads/2020/05/2018-2019-SKRIPTAZA-01-Bolonja.pdf>, 14. 5. 2020.

Ковачевић 2014: М. Ковачевић, „Може ли се рећи ја ћу да дођем?”, Језик данас, Х, 1-2, Нови Сад, 10-29.

Крцић 2018: Ненад Крцић, „Развијање стилских компетенција ученика (на примеру новинске вести)", Кюижевност и језик, LXV, 1-2, Београд, 137-151.

Мразовић/Вукадиновић 2009: P. Mrazović, Z. Vukadinović, Gramatika srpskog jezika za strance, Sremski Karlovci, Novi Sad: Izdavačka knjižarnica Zorana Stojanovića.

Наставни програм [НП]: Наставни програм Министарства просвете, науке и технолошког развоја Републике Србије: www.mp.gov.rs/propisi.

Николић 2009: М. Николић, Методика наставе српског језика и књижевности, Београд: Завод за уџбенике.

Пипер и др. 2005: П. Пипер, И. Антонић, В. Ружић, С. Танасић, Љ. Поповић, Б. Тошовић, Синтакса савременога српског језика, М. Ивић (ур.), Београд: Београдска књига, Институт за српски језик САНУ.

Симић/Јовановић 2007: Р. Симић, Ј. Јовановић, Српска граматика, Београд: Јасен.

Стевановић 1979: М. Стевановић, Савремени српскохрватски језик II, Београд: Научна књига.

\section{Nenad S. Krcić}

\section{STYLISTIC VALUES OF VERB FORMS IN SERBIAN LANGUAGE TEACHING}

\section{Summary}

The aim of this paper is to examine the share of stylistic information about verb forms in the current grammars of the Serbian language for primary school and high school and to compare these data with data from teaching practice obtained on the basis of survey-type research conducted among teachers. Based on these results, conclusions are given on the extent 
to which the stylistic value of verb forms is represented in teaching and suggests how teaching in this area could be improved and made more functional in the context of planned curriculum changes.

Keywords: verb forms, stylistic value, stylistics, methodics, Serbian language. 